\title{
Pengamatan Jenis Predator Hama Tanaman Padi Di Kampung Karya Bumi Distrik Waibu Kabupaten Jayapura
}

\author{
Jacob Julius Lawalata'; Khairul Anam² \\ STIPER Santo Thomas Aquinas Jayapura, Indonesia \\ lawalata_jacob@yahoo.co.id
}

\begin{abstract}
Abstrak
Musuh alami (parasitoid dan predator) pada hakekatnya secara alami dapat mengendalikan hama-hama yang menyerang tanaman padi pada semua tingkatan umur ketika lingkungan sekitarnya mendukung untuk perkembangbiakan musuh alami tersebut. Hal tersebut dimungkinkan karena ekosistem pertanian di Indonesia yang beriklim tropis ini sangat memungkinkan berkembangnya berbagai jenis musuh alami yang secara efektif dapat mengendalikan atau menekan populasi dari pada hama namun karena cara pengelolaan pertanian yang tidak tepat serta tidak berwawasan lingkungan seperti pemakaian pestisida yang tidak tertanggungjawab dapat menyebabkan terbunuhnya musuh-musuh alami yang ada. Tujuan dari pada penelitian ini adalah untuk mengetahui jenis - jenis predator hama tanaman padi di Kampung Karya Bumi Distrik Namblong Kabupaten Jayapura. Penelitian ini dilaksanakan di Kampung Karya Bumi Distrik Namblong Kampung Karya Bumi Distrik Namblong Kabupaten Jayapura dari bulan November - Desember 2017 dengan menggunakan metode survey dengan teknik pengumpulan data melalui observasi, wawancara dan studi pustaka. Hasil pengamatan musuh alami (predator) di Desa Karya Bumi Distrik Namblong Kabupaten Jayapura ditemukan tiga (3) jenis predator yaitu (1) Laba-Laba Pemburu (Lycosa sp), (2) Kepending Air (Microvelia douglasi atrolineata Berqroth) dan (3) Belalang Sembah (Mantis spp).
\end{abstract}

Kata kunci : Predator, Hama, Tanaman Padi

\section{PENDAHULUAN}

Serangga dalam sistem budidaya tanaman padi dapat digolongkan menjadi serangga netral, serangga yang berperan sebagai hama dan serangga berguna. Dimana ada serangga yang menjadi predator, parasitoid, decomposer atau pengurai dan serangga penyerbuk yang umumnya dikenal sebagai serangga-serangga berguna, namun ada juga serangga yang tidak tergolong dalam serangga berguna maupun serangga hama tetapi menjadi mangsa dari serangga predator, sehingga sangat memegang peranan penting dalam terciptanya keseimbangan ekosistem tanaman padi sawah. Namun dalam pandangan petani semua serangga adalah perusakan tanaman sehinga harus dikendalikan atau diberantas. Pada kenyataannya dalam suatu ekosistem padi sawah keanekaragaman jenis serangga mempunyai peranan penting dalam terciptanya keseimbangan ekosistem (Soelaksono, 2001 ; Siswanto \& Wiratmo, 2001 dalam Widiarta I Nyoman, Dede Kusdiaman, dan Suprihanto, 2006). 
Ekosistem alami pada waktu-waktu tertentu dapat menjaga sifat-sifat dalam ekosistem tersebut cukup konstan sebagai akibat dari desakan yang ditimbulkan oleh lingkungan fisik dan hubungan timbal balik baik intra spesies maupun antar spesies, dimana peristiwa mangsa-memangsa atau peristiwa predasi merupakan salah satu contoh mekanisme tersebut. Dalam suatu ekosistem, sifat predatisme ini akan senantiasa ada dalam suatu kehidupan organisme yang biasa dikenal dengan rantai makanan. Dimana dalam rantai makanan akan ada produsen yaitu tanaman dan konsumen yaitu pemakan tanaman (herbivore) dan musuh alami (karnivora) yang akan berlangsug sepanjang masa (Sunarno, 2012).

Penggunaan musuh alami dalam konsep pengelolaan dan pengenalian hama sehingga dapat menekan status suatu hama sebut pengendalian hayati, yang juga merupakan salah satu bagian dari konsep pengendalian hama secara terpadu. PHT merupakan suatu cara pandang atau konsep berpikir tentang pengendalian organisme penganggu tanaman (OPT) yang dilakukan dengan mempertimbangkan aspek ekonomi dan aspek ekologi guna tercapainya sistem pengelolaan agroekosistem yang berwawasan lingkungan yang berkelanjutan.

Musuh alami (parasitoid dan predator) pada hakekatnya secara alami dapat mengedalikan hama-hama yang menyerang tanaman padi pada semua tingkatan umur ketika lingkungan sekitarnya mendukung untuk perkembangbiakan musuh alami tersebut. Hal tersebut dimungkinkan karena ekosistem pertanian di Indonesia yang beriklim tropis ini sangat memungkinkan berkembangnya berbagai jenis musuh alami yang secara efektif dapat mengendalikan atau menekan populasi dari pada hama namun karena cara pengelolaan pertanian yang tidak tepat serta tidak berwawasan lingkungan seperti pemakaian pestisida yang tidak tertanggungjawab dapat menyebabkan terbunuhnya musuh-musuh alami yang ada.

Populasi hama khususnya pada tanaman padi sangat ditentukan juga oleh keberadaan atau kehadiran daripada musuh alami hama tersebut. Tingkat kepadatan populasi daripada suatu hama dapat menurun karena adanya parasitoid dan predator sebagai musuh alaminya juga kemampunan infeksi daripada JPS, dimana infeksi JPS dapat menyebabkan penurunan tingkat reproduksi, perkembangan serta ketahanan hama terhadap musuh alami serta pathogen bahkan dapat mematikan hama tersebut (Wardojo, 1986 dalam Santosa Sartono Joko dan Joko Sulistyo, 2007).

Sampai dengan saat ini keberadaan musuh-musuh alami (predator dan parasitoid) pada pertanaman padi yang dapat dipergunakan dan dikonservasi guna mengendalikan atau menekan perkembangan hama-hama utama pada tanaman padi di Kabupaten Jayapura secara khusus di Distrik Namblong belum pernah dilaporkan.

Adapun tujuan daripada penelitian ini adalah untuk mengetahui jenis - jenis predator hama padi di Kampung Karya Bumi Distrik Namblong Kabupaten Jayapura Provinsi Papua. 


\section{METODE PENELITIAN}

Penelitian ini dilaksanakan di lahan sawah milik petani yang berlokasi di Kampung Karya Bumi Distrik Namblong dengan menggunakann metode survey dengan teknik pengumpulan data melalui observasi, wawancara dan studi pustaka. Penentuan sampel dilakukan secara acak berdasarkan umur tanaman padi yaitu 30 hari, 40 hari dan 60 hari setalah tanam. Pengamatan di lakukan pada pagi hari. Pengumpulan musuh alami yaitu predator pada tanaman padi sawah dilakukan dengan menggunakan jaring serangga yang kemudian dimasukkan ke dalam plastic selanjutnya dibawa kelaboratorium untuk dilakukan pengamatan terhadap jenis predator hama padi yang terdiri dari jenis -jenis dan populasi spesies predator yang teridentifikasi di Kampung Karya Bumi Distrik Namblong Kabupaten Jayapura. Selanjutnya data hasil pengamatan dan identifikasi musuh alami pada tanaman padi sawah di Kampung Karya Bumi Distrik Namblong ditabulasi, disajikan dalam bentuk table dan narasi.

\section{HASIL DAN PEMBAHASAN}

Hasil pengamatan dan identifikasi terhadap serangga yang ditemukan di lokasi pengamatan yaitu Desa Karya Bumi Distrik Namblong ditemukan ada 3 jenis predator hama tanaman padi pada kondisi umur tanaman padi yang berbeda sebagaimana terlihat pada tabel 1 dan 2.

Tabel 1. Hasil pengamatan musuh alami hama tanaman padi di desa karya bumi

\begin{tabular}{|c|c|c|c|}
\hline No & Umur Tanaman Padi & Predator & Populasi \\
\hline \multirow{2}{*}{1} & \multirow{2}{*}{30 hari } & Kepinding Air & 6 ekor \\
\hline & & Laba-laba Pemburu & 8 ekor \\
\hline \multirow{2}{*}{2} & \multirow{2}{*}{40 har } & Kepinding Air & 7 ekor \\
\hline & & Laba-laba Pemburu & 11 ekor \\
\hline \multirow{3}{*}{3} & \multirow{3}{*}{60 hari } & Kepinding Air & 8 ekor \\
\hline & & Laba-laba Pemburu & 19 ekor \\
\hline & & Belalang Sembah & 3 ekor \\
\hline \multirow{2}{*}{4} & \multirow{2}{*}{90 hari } & Kepinding Air & 4 ekor \\
\hline & & Laba-laba Pemburu & 14 ekor \\
\hline \multirow{2}{*}{5} & \multirow{2}{*}{ Setelah panen } & Belalang Sembah & 3 ekor \\
\hline & & Laba-laba Pemburu & 15 ekor \\
\hline
\end{tabular}

Sumber: Data diolah, 2018

Tabel 2. Jenis-jenis predator hama tanaman padi di Desa Karya Bumi

\begin{tabular}{ccccc}
\hline No & \multicolumn{1}{c}{ Predator } & Nama Latin & Famili & Ordo \\
\hline 1 & Laba-Laba Pemburu & Lycosa sp & Lycosidae & Araneae \\
2 & Kepending Air & $\begin{array}{c}\text { Microvelia } \text { douglasi } \\
\text { atrolineata } \text { Berqroth }\end{array}$ & Velidae & Hemiptera \\
3 & Belalang Sembah & Mantis spp & Mantidae & Mantodea \\
\hline
\end{tabular}

Sumber: Data diolah, 2018 


\section{Median Volume 12 Nomor 1 Bulan Februari 2020}

Doi http://doi.org/md.v12i1.181

Konservasi musuh alami merupakan salah factor utama dalam menunjang keberhasilan program pengendalian hama secara hayati, maka tindakan eksplorasi musuh alami pada suatu daerah menjadi sangat penting karena melalui tindakan ini dapat diketahui musuh alami apa saja yang terdapat di daerah tersebut sehingga dapat dilakukan tindakan konservasi untuk melestarikan dan meningkatkan populasi musuh alami dimaksud.

Hasil eksplorasi musuh alami secara khusus predator hama pada tanaman padi sawah di Desa Karya Bumi Distrik Namblong hanya ditemukan 3 spesies predator yaitu Laba -Laba Pemburu (Lycosa sp), Kepending Air (Microvelia douglasi atrolineata Berqroth) dan Belalang Sembah (Mantis spp).

\section{Laba-Laba Pemburu (Lycosa sp)}

Fam. Lycosidae, Ordo. Araneae

Lycosa pseudoannulata Boes. et Str, sering ditemukan pada tanaman palawija dan padi sebagai laba-laba yang menjadi musuh alami dari hama tanaman padi dan palawija, oleh petani dinamakan Lycosa dan diketahui memiliki banyak mangsa terutama dari golongan serangga hama dan bersifat generalis (Arifin, 2005)

Menurut Arifin (2005) laba-laba Lycosa memilki tubuh relatif besar serta berwarna coklat tua serta memiliki empat mata kecil pada bagian anterior dan dua mata sedang serta dua mata besar pada bagian posterior.

Lycosa dikenal sebagai laba-laba buas (wolf spider) karena laba-laba ini menyerang dan memangsa mangsanya secara langsung serta tidak memasang jaring atau sarang sebagai perangkap untuk menangkap mangsanya. Kemampuan dalam memangsa nimfa dan imago hama wereng coklat pada tanaman padi yaitu 5-15 ekor/hari lebih tinggi dibandingkan kemampuan dalam memangsa hama utama tanaman kedelai (Shepard et al. 1987 dalam Arifin, 2005).

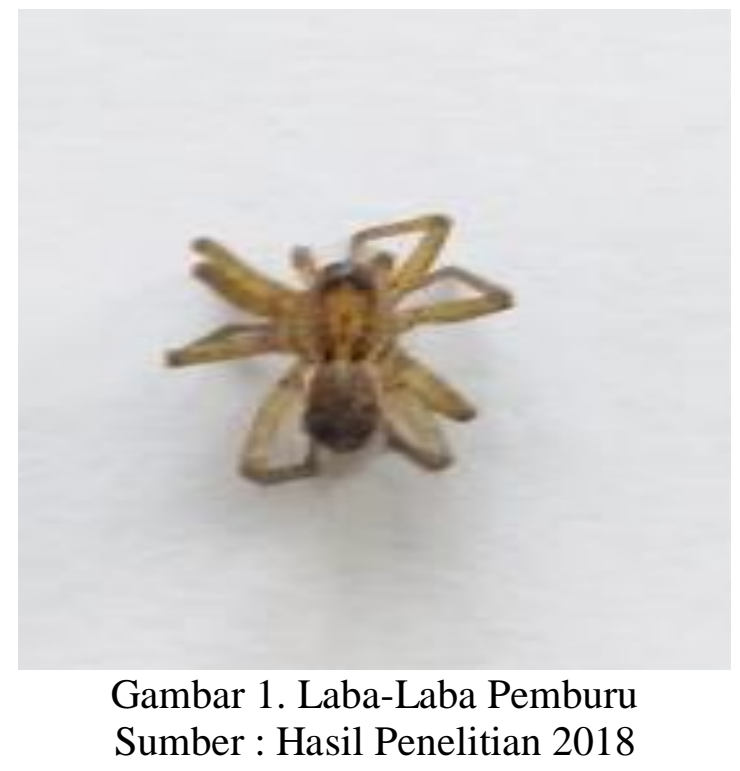

Pengamatan Jenis Predator Hama Tanaman Padi 


\section{Median Volume 12 Nomor 1 Bulan Februari 2020}

Doi http://doi.org/md.v12i1.181

\section{Kepending Air (Microvelia douglasi atrolineata Berqroth)}

Fam. Velidae, Ordo Hemiptera

Kepinding kecil ini dijumpai terutama pada petak-petak sawah yang sudah digenangi, dimana nimfa dan imagonya hidup pada permukaan air dan dikenal memiliki kemampuan bergerak seperti gelombang dan cepat. Imagonya memiliki ciri-ciri punggung yang lebar, ada yang bersayap dimana punggungnya memiliki gambaran warna putih dan hitam pada sayap depan dan leher serta ada yang tidak bersayap, memiliki ukuran yang kecil dan pada tarsi depannya hanya memiliki satu ruas. Telur diletakan pada batang padi yang terletak diatas permukaan air sebanyak 20-30 butir, kepinding ini dapat berpindah dari satu petak ke petak lain bila padi mengering terutama bagi kepinding yang memiliki sayap, serta dapat hidup selama $1-2$ bulan.

Imago dari kepending bergerombol di permukaan air dekat batang padi dan segera memakan nimfa wereng batang padi ketika jatuh ke permukaan air sedangkan nimfanya memangsa serangga lain yang tubuhnya lunak dan kecil termasuk nimfa wereng coklat. Microvelia dikenal sebagai predator yang suka menyerang mangsa secara berkelompok serta tidak menyukai mangsa yang berukuran lebih besar dan lebih tua. Dalam sehari seekor microvelia dapat memangsa 4-7 ekor wereng (Anonim, 2011).

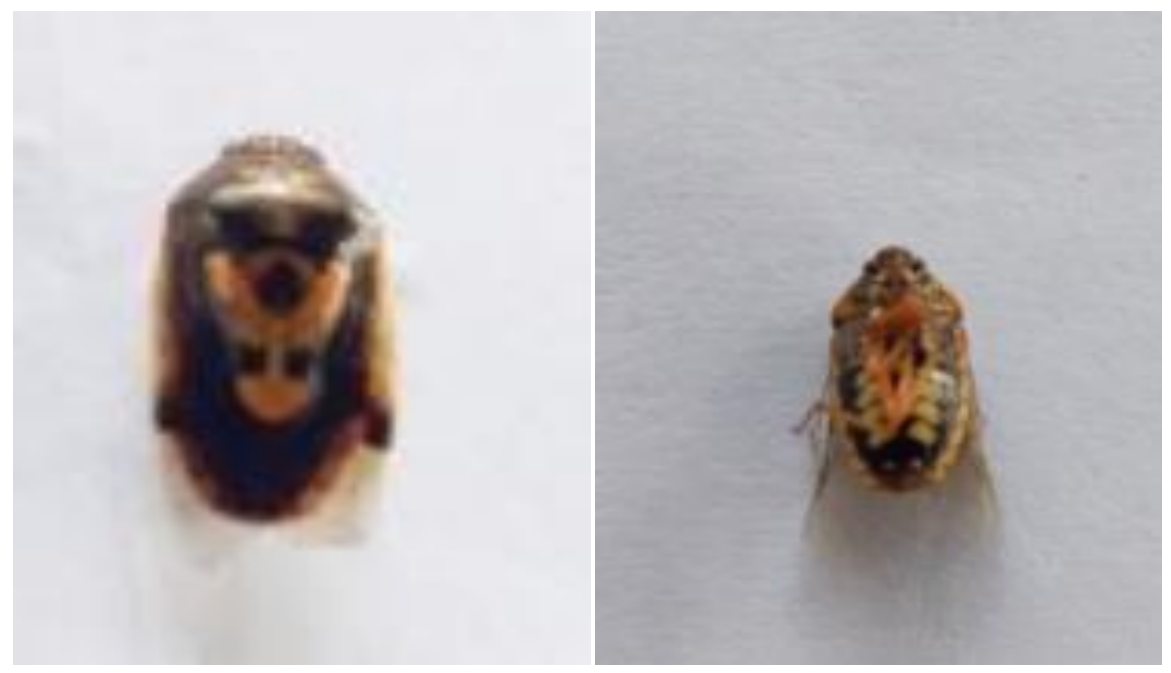

Gambar 2. Kepinding Air

Sumber : Hasil Penelitian 2018

\section{Belalang Sembah (Mantis spp)}

Fam. Mantidae, Ordo. Mantodea

Belalang sembah merupakan belalang dari ordo Mantodea yang memiliki kemampuan untuk berkamuflase dan mimikri dengan lingkungan sebagai cara salah satu dalam beradaptasi sekaligus mencari mangsanya. Dikenal sebagai predator dari beberapa serangga seperti kutu daun, ngengat, belalang, kupu-kupu dan lalat (Sureshan dan Sambath, 2009 dalam Sugiarto, 2018).

Menurut Herlinda dkk (2010), Manthis sp. atau belalang sembah adalah kelompok belalang yang menjadi predator daripada Lipaphis erysimi. Memiliki ciri-ciri sebagai 
Doi http://doi.org/md.v12i1.181

berikut : tubuh memanjang dan besar serta berwarna coklat muda, femur memiliki berduri, tungkai depan kuat dan panjang yang berguna untuk menangkap mangsa, pada caput terdapat sepasang antenna yang pendek, berbentuk filiform, memilki mata majemuk atau faset serta alat mulut berbentuk vertical atau hipognatus.

Bagian toraks terbagi atas tiga yaitu protoraks, mesotoraks dan metatoraks, dimana pada masing-masing terdapat sepasang tungkai. Protoraks memiliki ukurang panjang $18 \mathrm{~mm}$. Ukuran panjang tungkai pertama $68 \mathrm{~mm}$, tungkai kedua $64 \mathrm{~mm}$ dan tungkai ketiga $72 \mathrm{~mm}$ dengan tipe tungkai berbentuk raptorial. Memiliki 3 pasang femur, memiliki 3 pasang tibia yang terdapat duri, memikili 3 pasang tarsus, memiliki 3 pasang kuku tarsus, memiliki 3 pasang trokhantor, memiliki 2 pasang sayap di mana panjang sayap depan ukuran $54 \mathrm{~mm}$ dan sayap belakang berukuran $44 \mathrm{~mm}$. Pada bagian abdomen terdapat 8 ruas (Ledheng dkk, 2016).

Menurut Sureshan dan Sambath, (2009) dalam Sugiarto (2018) kupu-kupu, lalat, ngengat, kutu daun maupun belalang merupakan mangsa dari pada belalang sembah, sedangkan Dwari dan Amal (2018) mengatakan bahwa populasi serangga yang berbahaya pada ekosistem persawahan dan perkebunan dapat dikontrol atau dikendalikan oleh belalang sembah.

Sedikitnya musuh alami (predator) yang ditemukan di daerah eksplorasi yaitu Desa Karya Bumi Distrik Namblong sebagaimana terlihat pada tabel 1 diduga dipengaruhi oleh pola pengendalian hama utama tanaman padi yaitu menggunakan pengendalian kimiawi sebagai alternative pengendalian utama. Hasil wawancara dengan petani padi yang ada diperoleh informasi bahwa pengendalian hama dicara secara seporadik yaitu ketika ada serangan hama maka pengendalian dilakukan dengan frekuensi penyemprotan yang tidak menentu sehingga sangat berpengaruh terhadap ketersediaan serangga hama sebagai sumber pakan atau mangsa dari predator-predator yang biasanya terdapat pada pertanaman padi sawah.

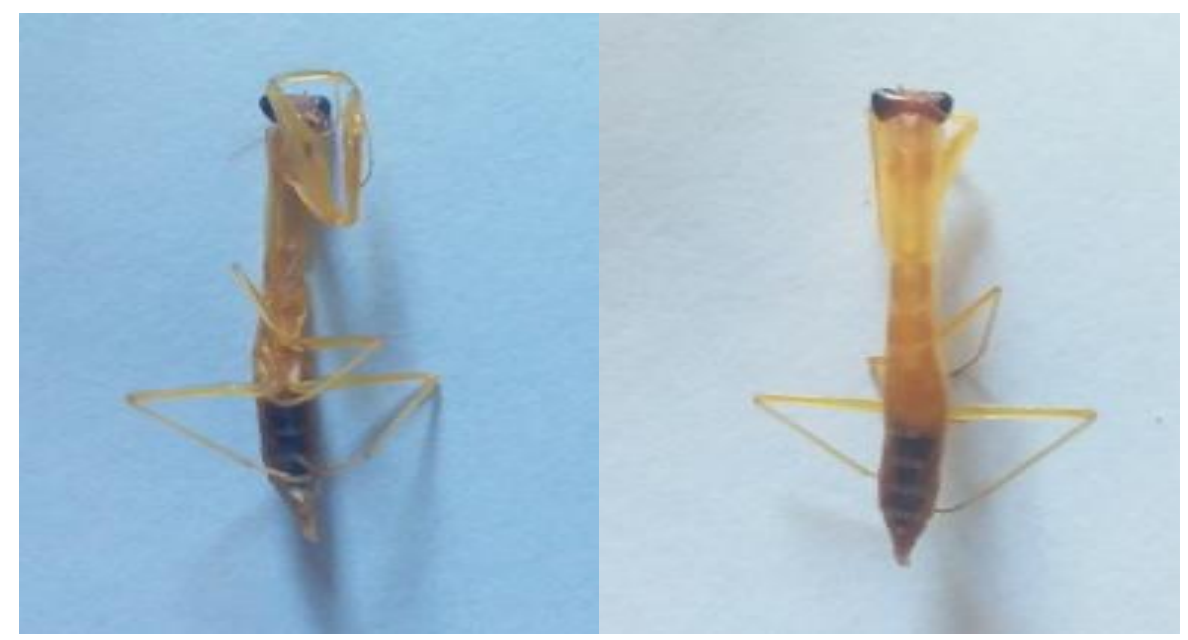

Gbr. 3. Belalang sembah

Sumber : Hasil Penelitian 2018 
Keberadaan, populasi serta tingkat predasi suatu musuh alami (predator) pada suatu tempat sangat dipengaruhi oleh keberadaan serangga hama atau mangsa baik dari segi jumlah maupun jenis serangga hama yang ada bagi masing-masing predator tersebut.

Penggunaan pestisida yang bekerja sebagai racun kontak secara tidak terkontrol serta tepat dosis dapat memberikan dampak yang negative terhadap keberadaan dan populasi serangga-serangga berguna yaitu predator dan parasitoid maupun seranggaserangga netral yang juga merupakan mangsa dari pada predator. Hal ini diduga dialami atau terjadi di daerah pesawahan milik petani di Desa Karya Bumi, dimana hasil wawancara dengan petani sampel diperoleh data bahwa semua jenis insektisida yang digunakan dalam pengendalian hama bekerja sebagai insektisida racun kontak dan lambung.

\section{KESIMPULAN}

Berdasarkan hasil pengamatan musuh alami (predator) di Desa Karya Bumi Distrik Namblong Kabupaten Jayapura ditemukan tiga (3) jenis predator yaitu (1) LabaLaba Pemburu (Lycosa sp), (2) Kepending Air (Microvelia douglasi atrolineata Berqroth) dan (3) Belalang Sembah (Mantis spp).

\section{DAFTAR PUSTAKA}

Anonim, 2011. Predator - kepinding air (jenis yang membantu petani), Kementerian Pertanian, Badan Penyuluhan dan Pengembangan Sumber Daya Manusia Pertanian, http://cybex.pertanian.go.id/ materi penyuluhan /cetak/3343

Arifin, M. 2005. Lycosa pseudoannulata: laba-laba pemangsa serangga hama kedelai. Berita Puslitbangtan. 32: 8-9.

Herlinda S, Cheppy Wati, Khodijah, Haperidah Nunilahwati, Dewi Meidalima, dan Abdul Mazid, 2010. Eksplorasi dan Identifikasi Serangga Predator Lipaphis erysimi (Kalt.) (Homoptera: Aphididae) dari Ekosistem Sayuran Dataran Rendah dan Tinggi Sumatera Selatan, Seminar Nasional hasil Penelitian Bidang Petanian, Palembang 20 Oktober 2010

Ledhenga L, Theresia Enob dan Blasius Atinic, 2016. Inventarisasi Serangga Predator Hama Padi Pada Areal Pertanian Desa Letmafo Kecamatan Insana Tengah. Bio - Edu : Jurnal Pendidikan Biologi, International Standard of Serial Number 2527-6999, Vol. 1, No. 2 (24-26)

Santosa Sartono Joko dan Joko Sulistyo, 2007. Peranan Musuh Alami Hama Utama Padi Pada Ekosistim Sawah, Jurnal Inovasi Pertanian Vol. 6, No. 1, 2007 (1 $10)$.

Sugiarto A, 2018. Inventarisasi Belalang Sembah (Mantodea) di Desa Serdang Menang, Kecamatan Sirah Pulau Padang, Kabupaten Ogan Komering Ilir, Kumpulan artikel Insect Village, Vol 1, No 1, 4-6 


\section{Median Volume 12 Nomor 1 Bulan Februari 2020}

Doi http://doi.org/md.v12i1.181

Sunarno, 2012. Pengendalian Hayati (Biologi Control) Sebagai Salah Satu Komponen Pengendalian Hama Terpadu (PHT). https://journal.uniera .id/pdf_ repository/juniera31uHIhqLaBkzzrDBMOhRadqxY8H.pdf, di akses 15 Oktober 2017.

Widiarta I Nyoman, Dede Kusdiaman, dan Suprihanto, 2006. Keragaman Arthropoda Pada Padi Sawah Dengan Pengelolaan Tanaman Terpadu, Jurnal. HPT Tropika. ISSN 1411-7525 61 Vol. 6, No. 2 : $61-69$. 